\title{
Capturing Social Issues Through Signs: Linguistic Landscape in Great Malang Schools, Indonesia
}

\author{
Sumarlam, Dwi Purnanto, Dany Ardhian* \\ Linguistics Post-Graduate Program, Faculty of Cultural Science, Universitas Sebelas Maret, Surakarta 57126, Indonesia
}

Corresponding Author Email: danyardhian@ub.ac.id

https://doi.org/10.18280/ijsdp.160320

Received: 11 August 2020

Accepted: 20 May 2021

\section{Keywords:}

social issues, character education, Great Malang schools, language use, Linguistic Landscape

\begin{abstract}
This study aims to analyze the signs associated with social issues in school spaces by using the Linguistic Landscape approach. Data were obtained from 10 public and private schools in Great Malang, Indonesia through photography. The study reports several findings, namely (1) Indonesian schools are monolingual, bilingual, and multilingual with the dominant use of Bahasa, English, Arabic and Javanese, (2) phrases and clauses dominate the appearance of data in linguistic aspects, compared to words. Therefore, they are very effective in mediating messages conveyed in signs, (3) it comprises of eight themes, namely environment, juvenile delinquency, health, discipline, motivation, attitude and behavior, religion, and nationalism, (4) there are 9 out of 18 values of character education, namely hard work, creative, discipline, national spirit, religious, honest, environmental care, reading hobby, and love for peace. In conclusion, Bahasa Indonesia is associated with the symbol of nationalism and language policy, where English, Arabic and Javanese symbolize modernization, Islam, and the local culture, respectively. Furthermore, the themes and values of character education that emerge represent the conditions of the problems faced by students. This finding suggest education through signs, evoke perceptions and attitudes which is used to strengthen character education in schools to solve social problems.
\end{abstract}

\section{INTRODUCTION}

Language plays an essential role in conveying information, promoting and representing certain symbols and accommodating the needs of writers for their messages to be conveyed in wider society. Furthermore, Public space is associated with language performance and contestation which acts as a means to instill and educate moral values to the community. The presence of languages in public spaces signifies social existence and it is used by schools to promote and instill educational values and morality for schools, teachers, and surrounding communities.

Linguistic Landscape (LL) is a study that analyzes texts displayed in public spaces to determine the information and symbolic functions in texts [1]. In addition, Huebner [2] and Backhaus [3] stated that LL attempts to investigate social aspects and also serves to uncover the heterogeneity of language and sociolinguistic contexts inherent the use, perception, attitude, status, role, function, and language policy [4].

The presence of a language in the public space signifies the existence of the user community with the ability to accommodate the understanding of language speakers. Furthermore, language is also able to convey issues of nationalism, modernity, and locality, which tend to compete for space through promotion. The superiority of a language in accommodating modernization and globalization is an important promotional factor. English accommodates the education and trade domains and helps to incorporate the society into the global and modern realm. Language policy also influences the frequency of usage with government regulations used to create high vitality and strength. Language is also used to show local identity with the regional appearance in public spaces indicating its relevance to the needs of speakers and their locality [5].

Monolingual texts indicate that the language's prestige and strength are only used by one particular community without the support and assistance of others. Conversely, texts written in two or more languages are better understood in heterogeneous communications [6]. The existence of a language in the public sphere is associated with accommodating the interests of speakers in understanding text messages, and the symbolic representation [7]. For example, the use of English in the world of commerce is used to illustrate the symbol of success and international orientation $[8,9]$. English is considered capable of inviting foreign investment to participate and accelerate the development process of the business world, as seen from the low ability and understanding of language speakers [10]. Furthermore, English is used to determine when internationalization is more important than understanding in society. LL studies carried out at schools are used to explain the language situation, text makers, target readers, messages conveyed, and language policies applied. Then language situation is related to its use in an area, which is reflected in the public space. The text creator also considers the target reader to ensure the message conveyed is received with LL used as a source of language learning and literacy [10-13].

Malang City is an urban area with the education, business and tourism industries responsible for making the city a 
domicile destination. However, this tends to affect the surrounding environment, such as Batu City. The local people of Great Malang speak Bahasa Indonesia and regional languages such as Javanese and Madurese. Bahasa Indonesia is used in formal oral and written communication, while Javanese and Madurese are used in informal and oral communication. Furthermore, English is also studied at schools as a compulsory subject, unlike the Javanese language that is learned as a local content lesson.

Bahasa Indonesia and Javanese are used to make formal and informal speeches in schools. English is rarely used in communication, however, the texts displayed in public spaces around the school premises comprises of Bahasa Indonesia, English, Arabic, and Javanese languages. Therefore, English is a unique language used by text writers to target readers, of various communities. Schools are gateways to knowledge and also act as a medium for the education of national character values. The Indonesian government started the implementation of character education at all levels in the 2011/2012 school year to produce noble, democratic, responsible, healthy, and creative students. In character education, the government provided a reference to 18 components, namely (1) religious, (2) honesty, (3) tolerance, (4) discipline, (5) hard work, (6) creativity, (7) independent, (8) democratic, (9) curiosity, (10) national spirit, (11), love of the motherland, (12) respect for communication, (13) friendly/communicative, (14) peace-loving, (15) fond of reading, (16) care for the environment, (17) social care, and (18) responsibility. In addition to learning character education, character education is promoted through signs and posted in the environment around schools.

LL studies in bilingual cities were reported in several studies, carried out in Jerusalem [7, 14], the Netherlands and Spain [15]. It was also carried out in multilingual cities such as in Lita, Uganda [16], Rome [17], Bangkok [2], and Tokyo [3], Kuala Lumpur [18, 19], Dilli, Timor Leste [20], Singapore $[21,22]$ and Bangkok, Thailand [23]. LL studies were further examined city setting in Indonesia carried out by [4, 24-29]. Only two study conducted in Indonesia that focus on school sign, that is [4] and [27]. There are differences between this study and the previous. Previous studies have focused more on texts available in public spaces in a school, then analyzed the frequency of language use, information, and symbolic functions. Furthermore, LL studies on school scape have nothing to do with educational values. In addition, previous research was unsuccessful in reaching text themes in the public space of school so that the big picture of the public space text was less legible. With some of these gaps, this study aims to reach them. This study aims to (1) describe the form and frequency of language, as well as the linguistic aspects involved in the signs, themes, and values of character education represented by LL signs in Great Malang schools; (2) LL texts in the school scape area contain motivations, invitations, and prohibitions targeted at readers. This LL analysis seeks to dismantle the use of language to communicate the value of character education through signs in the school area.

\section{METHOD}

Data was obtained from signs displayed in schools in Great Malang, namely Malang City, Malang Regency, and Batu City. This study took data from 10 samples of schools that often raised environmental issues and educational values. Six public schools were selected, SMAN 2 Malang, SMKN 4 Malang, SMKN Singosari, SMPN 1 Singosari, SMPN 1 Batu, SMPN 4 Batu and four selected private schools are SMA BSS, SMA Panjura, SMP Shalahudin, SMP Diponegoro (Table 1). These two types of schools were chosen to see how public and private schools deal with environmental and social issues, as well as how character education is applied through text in public spaces. Researchers found that many texts were scattered in the school's public space. However, many texts are not under the purpose of the research so they are ignored.

The posters were found in parks, canteens, parking lots, schoolyards, class aisles, libraries, places for ablution, as well as prayer, teacher, and classrooms. One of the posters consists of text which is the primary data, while images, photos, colors are the secondary data with contextual values [4].

The school environment comprises of warning signs, instructions, and announcements. This study uses the sign that contains the value of character education in from the Center for Curriculum Development and Cultural Education and Nation Character (2009) which comprises of 18 characterforming values sourced from religion, Pancasila, namely (1) religious, (2) honest, (3) tolerance, (4) discipline, (5) hard work, (6) creative, (7) independent, (8) democratic, (9) ) curiosity, (10) the spirit of nationalism, (11) love for motherland, (12) respect for achievement, (13) friendly/communicative, (14) love of peace, (15) desire to read, (16) care for the environment, (17) social care, and (18) responsibility. However, not all character education values were applied because they were selected based on social problems experienced by students and the community. Furthermore, signs are displayed to educate and help solve social problems around students and schools.

Data was collected from 108 photos in 10 public and private schools through documentation (photography) and analyzed using codification. Table 1 shows the distribution of data on State High School coded A1, Private High School coded A2, Vocational High School coded K1, Public Junior High School coded P1 and Private Junior High School coded P2.

Table 1. Distribution of data based on school

\begin{tabular}{|c|c|c|c|c|}
\hline No & School & Code & City & $\begin{array}{c}\text { Number } \\
\text { of Data }\end{array}$ \\
\hline 1 & SMAN 2 & A1-1 & Malang City & 14 \\
\hline 2 & SMA BSS & A2-1 & Malang City & 6 \\
\hline 3 & SMA Panjura & A2-2 & Malang City & 8 \\
\hline 4 & SMKN 4 & $\mathrm{~K} 1-1$ & Malang City & 21 \\
\hline 5 & $\begin{array}{c}\text { SMKN } \\
\text { Singosari }\end{array}$ & $\mathrm{K} 1-2$ & Malang Reg. & 6 \\
\hline 6 & $\begin{array}{l}\text { SMPN } 1 \\
\text { Singosari }\end{array}$ & $\mathrm{P} 1-1$ & Malang Reg. & 9 \\
\hline 7 & SMPN 1 & $\mathrm{P} 1-2$ & Batu City & 7 \\
\hline 8 & SMPN 4 & P1-3 & Batu City & 17 \\
\hline 9 & $\begin{array}{c}\text { SMP } \\
\text { Shalahudin }\end{array}$ & $\mathrm{P} 2-1$ & Malang City & 5 \\
\hline 10 & $\begin{array}{c}\text { SMP } \\
\text { Diponegoro } \\
\text { Total } \\
\end{array}$ & P2-2 & Batu City & $\begin{array}{c}15 \\
108\end{array}$ \\
\hline
\end{tabular}

Data distribution was carried out using analysis of domains, taxonomies, components, and cultural themes as stated by Spradley [30]. In domain analysis, the study was classified based on school, sign, and permanent/temporal location. According to Wohlfart [31], location is an important consideration because it correlates with the number of signs 
placed in the environment and around the park. Signs that are permanently posted indicate the value of character education, which is the hallmark of schools. Meanwhile, temporarily displayed signs indicate problems faced or the school agenda. For example, in afforestation, signs are displayed to welcome the arrival rainy seasons which causes many landslides and floods. Taxonomic analysis functions to accommodate the work of the LL to describe the form of language, the frequency of usage, linguistic structure, themes, and values of character education. The form of language use is carried out based on monolingual, bilingual, and multilingual classification. The frequency of language use is obtained from the appearance of data based on its formation with the theme analysis classified in accordance with the themes. The character education is classified based on 18 component values, while in the component analysis, domains and taxonomies where used for cultural themes that are built. An example includes analyzing the social problems that arise from students and the surrounding communities.

\section{RESULTS AND DISCUSSION}

This section discusses the forms of language, linguistic, themes, and values of character education built-in schools.

\subsection{Form of language use in LL school scape}

LL analysis comprises of three forms of language, namely monolingual, bilingual, and multilingual which comprises of Indonesian, English, Java, and Arabic as shown in Table 2. Indonesian and English are involved in monolingual, bilingual, and multilingual. Javanese is not involved in bilingual and multilingual forms, while Arabic is only involved in bilingual and multilingual. The highest frequency of occurrence was shown by the Indonesian monolingual form (84.3\%) followed by the bilingual Ind+Eng (10.2\%) and monolingual English $(2.8 \%)$.

Table 2. Forms of language use and the number of occurrences

\begin{tabular}{cccccccc}
\hline School & \multicolumn{3}{c}{ Monolingual } & \multicolumn{2}{c}{ Bilingual } \\
Ind & Eng & Jav & $\begin{array}{c}\text { Multilingual } \\
\text { Eng }\end{array}$ & $\begin{array}{c}\text { Tnd+ } \\
\text { Arab }\end{array}$ & $\begin{array}{c}\text { Ind+Eng } \\
\text { +Arab }\end{array}$ & \\
\hline $\mathrm{A} 2-1$ & 5 & 0 & 0 & 0 & 0 & 1 & 6 \\
$\mathrm{~A} 2-2$ & 6 & 0 & 0 & 2 & 0 & 0 & 8 \\
$\mathrm{~A} 1-1$ & 12 & 1 & 0 & 1 & 0 & 0 & 14 \\
$\mathrm{~K} 1-1$ & 21 & 0 & 0 & 0 & 0 & 0 & 21 \\
$\mathrm{P} 2-1$ & 4 & 0 & 0 & 1 & 0 & 0 & 5 \\
$\mathrm{~K} 1-2$ & 4 & 0 & 0 & 2 & 0 & 0 & 6 \\
$\mathrm{P} 1-1$ & 7 & 0 & 0 & 2 & 0 & 0 & 9 \\
$\mathrm{P} 1-2$ & 7 & 0 & 0 & 0 & 0 & 0 & 7 \\
$\mathrm{P} 1-3$ & 15 & 1 & 0 & 1 & 0 & 0 & 17 \\
$\mathrm{P} 2-2$ & 10 & 1 & 1 & 2 & 1 & 0 & 15 \\
Total & 91 & 3 & 1 & 11 & 1 & 1 & 108 \\
& $84.3 \%$ & $2.8 \%$ & $0.9 \%$ & $10.2 \%$ & $0.9 \%$ & $0.9 \%$ & \\
\hline
\end{tabular}

Public schools such as K1-1 (21), P1-3 (17), and A1-1 (14) have the highest frequency of signs, with P2-2 (15) as the only private school with a high frequency. Although K1-1 has the highest data, it only engages in one form, namely Indonesian monolingual which is different from P2-2, in five forms.

\subsection{Monolingual signs in LL school scape}

There are three languages involved in the monolingual form: Bahasa Indonesia, English, and Javanese. Monolingual frequency in Bahasa Indonesia is very dominant compared to English and Javanese. Ardiyanti [4], Harbon and Halimi [27] stated that the application of the Bahasa Indonesia as the official language indicates that it is easy to understand.

Figure 1 was permanently placed in front of the class room, thereby enabling students to read it daily. The combination of text, color (black and red), font size, and images supports the delivery of motivational messages to students. Bahasa Indonesia was chosen to facilitate the reader's perception of text messages in order to optimally convey motivational messages.

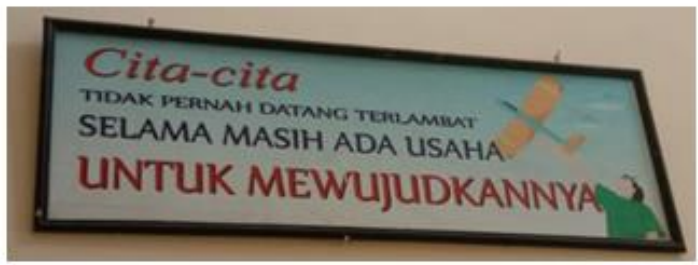

Figure 1. Monolingual sign in Bahasa Indonesia: Permanent text $(\mathrm{A} 2-1 / 1)$

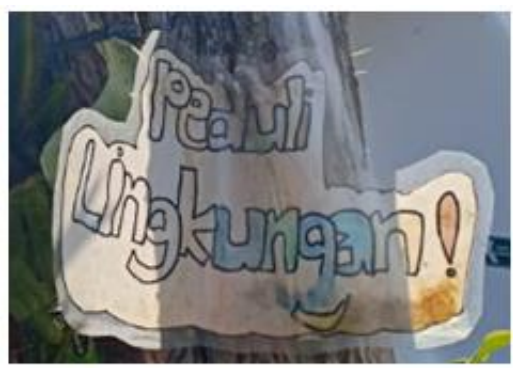

Figure 2. Monolingual sign in Bahasa Indonesia: Temporal text $(\mathrm{P} 1-3 / 45)$

Figure 2 was placed on the tree, in the garden school area with the phrase "Peduli Lingkungan" which means Care for the Environment. This aims to educate students to preserve the environment, especially the trees around the school. Bahasa Indonesia was chosen to provide an understanding of the message conveyed, while the phrase was used to make the message easy to remember. In addition, the language is used as a symbol of nationalism and policy.

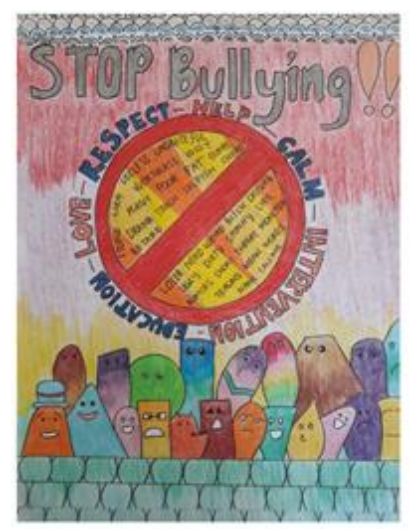

Figure 3. Monolingual sign in English (A1-1/83) 
The sign above shows that English is used to convey international messages (Figure 3). The "STOP Bullying" clause gives clear details of the components, namely love, respect, help, calm, intervention, and education. The English language used indicates that the problem of bullying is universal and common in high schools. The message is different when used in Indonesian or Javanese because issues associated with bullying tends to become national or local. Previously, the issue of bullying had become a norm for senior students to the juniors. However, schools abroad failed to recognize this fact. Therefore, the functions of English in above sign attract international issues to national or vice versa. The caricature displayed supports the text to give a sinister picture of the issue of bullying.

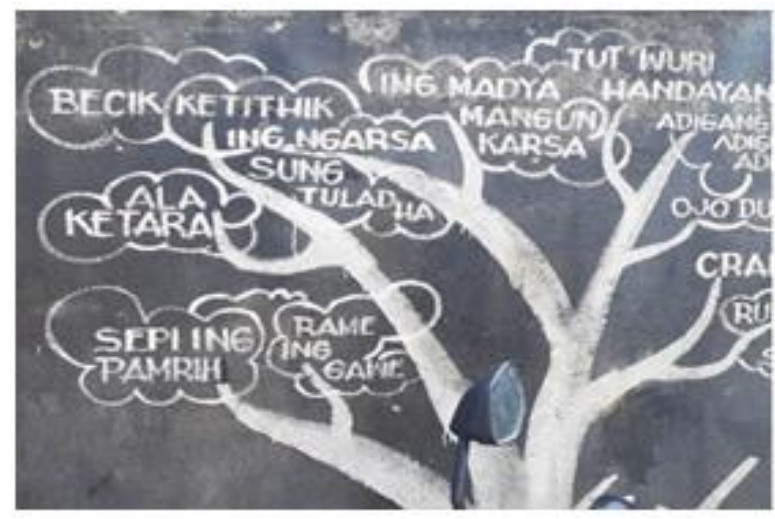

Figure 4. Monolingual sign in Javanese proverb (p2-2/65)

Figure 4 shows that local languages such as Javanese are relevant for communicating educational messages. The sign above is on the wall of the school parking lot with the Javanese proverb such as "Becik ketithik ala ketara means Goodness and badness is seen, Sepi ing pamrih rame ing gawe means Do not expect rewards and always be enthusiastic at work, Ing ngarsa sung tuladha, Ing madya mangun karsa, Tut wuri handayani means In front, middle and behind giving direction, building enthusiasm, and giving encouragement. Adigang adigung, adiguna means We need to rely on strength, power, and intelligence possessed Ojo dumeh" means do not be arrogant. The use of the Javanese language indicates that many students are of Javanese ethnicity. Text placement in students' parking lot indicates that it is an important and often problematic area at this location. Tree image that resembles mind mapping shows the learning that teachers often use in the classroom, therefore they are considered familiar to the students. The use of Javanese proverbs indicates cultural symbols that are promoted through signs [4].

\subsection{Bilingual sign in LL school scape}

The bilingual form consists of two combination patterns, namely Indonesian + English and Indonesian + Arabic and these emerge due to the translation and affirmation that are interrelated between the two languages.

Figure 5 shows an English translation into Indonesian with the sign located at the entrance to the teacher's room. This means that the text is addressed to students, and teacher. English is used as a sign of internationalization, while the Indonesian translation is used to provide a clearer message [4]. Red background with a student picture indicates that this message is affirmative. The messenger expects the teacher to properly teach and educate students.

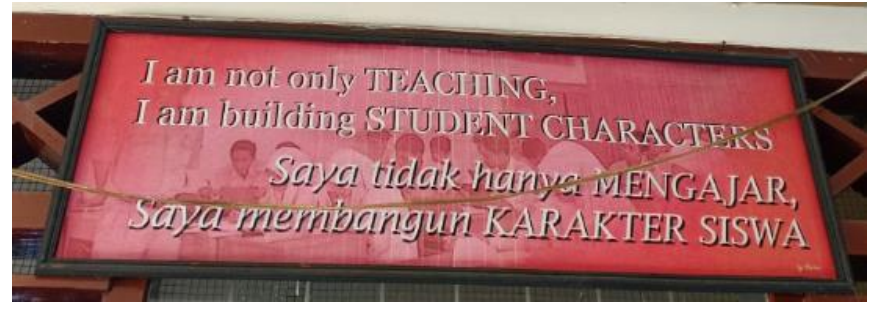

Figure 5. Bilingual sign in English and Bahasa Indonesia: translation (P1-3/42)

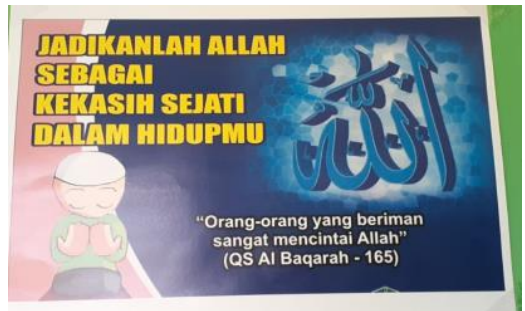

Figure 6. Bilingual sign in Bahasa Indonesia and Arabic script (P2-2/71)

Figure 6 consists of three texts with two types of scripts, Arabic and Latin as well as a third text, which acts as an affirmation. Correlation in the three texts is the word of God. The clause "JADIKAN ALLAH SEBAGAI KEKASIH SEJATI $D A L A M$ HIDUPMU" means let Allah be the true love in your life, is a motivation that is created based on the purpose of the verses in the Alquran. As for the reinforcement, the Arabic script is used to strengthen faith, while Latin reduces the power of meaning. Background images of children praying using Muslim identity (kopyah) make it clear that the text is a prayer. Arabic script is used to mark the symbol of Islam. This text is used because the majority of students and teachers are Muslim utilize Arabic, therefore, the use of Arabic script facilitates the perception of the text to be conveyed.

\subsection{Multilingual sign in LL school scape}

The multilingual form is a combination of English, Bahasa Indonesia, and Arabic. These languages use the Latin script with the combination of Indonesian and Arabic to form mixed codes.

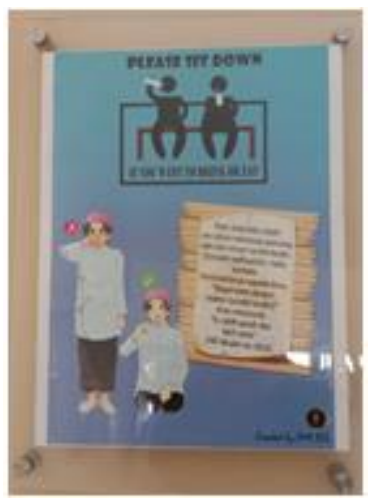

Figure 7. Multilingual sign English, Bahasa Indonesia, and Arabic with mixcode (A2-1/6) 
The important message highlighted in Figure 7 was written in English "PLEASE SIT DOWN IF YOU WANT TO DRINK OR EAT. The English text stands at the top, while the text below forms the Bahasa Indonesia and Arabic mix codes with Latin script. Arabic appears in mix codes because the translation in other languages reduces the power of meaning. ".. Sallallahu 'alaihi wa salam' and "Radhiyallahu 'Anhu" is a binding religious term. Background illustrated images support the message and text purpose.

\subsection{Linguistic aspects in LL school scape}

Sign in school scape is oriented towards educational messages. The success of the message depends on the use of language, picture illustrations and the linguistic aspects. This study found three forms of linguistic usage, namely phrases, clauses, and combinations as shown in Table 3.

Table 3. Distribution of linguistic aspect in LL school scape

\begin{tabular}{ccccc}
\hline Phrase & Clause & $\begin{array}{c}\text { Combination } \\
\text { Word+ } \\
\text { Phrase }\end{array}$ & $\begin{array}{c}\text { Word+ } \\
\text { Phrase+ } \\
\text { Clause }\end{array}$ & $\begin{array}{c}\text { Phrase+ } \\
\text { Clause }\end{array}$ \\
\hline 2 & 76 & 3 & 1 & 26 \\
$1.85 \%$ & $70.4 \%$ & $2.78 \%$ & $0.93 \%$ & $24.1 \%$ \\
\hline
\end{tabular}

The clause has the highest frequency $(70.4 \%)$ followed by the phrase + clause structure $(24.1 \%)$, which are almost involved in all distributions. These findings indicate that the structure of phrases and clauses is very effective for conveying messages in signs. Words only appear in combination with both phrases and clauses with a small frequency of occurrence. This indicates that the word is less effective in conveying messages autonomously.

The appearance and combination of clauses also indicate that the messages in the text are interrelated and mutually supportive. The texts are also supported with picture illustrations, as well as various font sizes, and colors. Text and image games strongly support the delivery of messages with specific characteristics in each of the themes and components of character education, as well as the linguistic aspects used in delivering messages. This style also contributes to the reader's perception with certain themes easier to perceive using linguistic aspects than others. However, overall, phrases and clauses are still effective in conveying messages in the school scape.

\subsection{The theme in $L L$ school scape}

The sign raised several themes, namely environment, juvenile delinquency and prevention, health, discipline, motivation, attitudes and behavior, religion, and nationalism (nationality) themes. Environment themes became the most dominant issue with the frequency of data appearing 30 times $(27.8 \%)$, followed by motivational $(24.1 \%)$, as well as attitudes and behavior $(18.5 \%)$. The theme of juvenile delinquency and health is an intermediate issue, while that of religion and nationalism rarely appears $(1.9 \%)$ as shown in Table 2 and diagram 1.

From Table 4 and diagram 1, shows that the themes that often emerge sequentially are environment, motivation, attitudes and behavior, juvenile delinquency, health, discipline, religion, and nationalism. Environment themes are used to promote topics associated with saving water, garbage, greening, cleanliness, saving trees, saving energy. The above tables and diagrams, show the theme of the environment is a very dominant developing issue which indicates that environmental problems are crucial and widespread in the community, especially the younger generation. Furthermore, the environment experiences weaknesses in terms of concern for the environment with the issues of clean water, greening, rubbish, global warming associated with schools, communities, and countries. The United Nations World Health Organization (WHO) is also concerned with environmental issues, especially those associated with the provision of clean water.

Table 4. LL theme

\begin{tabular}{cccccccc}
\hline T1 & T2 & T3 & T4 & T5 & T6 & T7 & T8 \\
\hline 30 & 11 & 11 & 3 & 26 & 20 & 2 & 2 \\
27.8 & 10.2 & 10.2 & 2.8 & 24.1 & 18.5 & 1.9 & 1.9 \\
$\%$ & $\%$ & $\%$ & $\%$ & $\%$ & $\%$ & $\%$ & $\%$ \\
\hline
\end{tabular}

Notes:

Theme 1 (T1) : Environment

Theme 2 Juvenile delinquency

Theme 3 (T3): Healthy

Theme 4 (T4): Discipline

Theme 5 (T5): Motivation

Theme 6 (T6): Attitudes \& behaviour

Theme 7 (T7): Religion

Theme 8 (T8): Nationalism

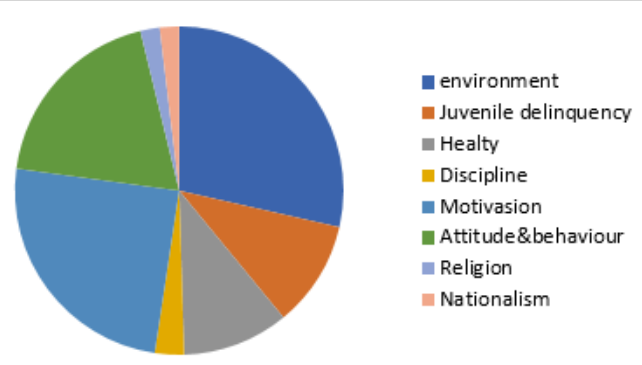

Diagram 1. Distribution of theme

The next issue that develops in schools is motivation, which is relevant to the learning community because it enables students to possess enthusiasm which becomes a good habit for them. The next issue that arises with high frequency is attitude and behavior which is relevant for the younger generation. Schools need to instil an attitude of respect, courtesy, assistance, cooperation, care, and tolerance in students. Introduction of these attitudes enables students to determine the best way to deal with the community and society. Also presented in the table is juvenile delinquency issues $(10.2 \%)$ which are also relevant to students conditions for instance, drugs are very dominant. This issue was introduced to provide a discourse on the dangers of drugs and premarital sex for students. This issue of sexuality tends to set a bad precedent with the rapid development of information technology that provides access to various pornographic videos, images, or writings that tend to sexually provoke young generation. Therefore, assuming this issue is not properly directed, with a deep explanation of moral values, it is feared that the next generation of the nation's young people is likely to participate premarital sexuality which will undermine their future.

Health issues also arise with a frequency of $10.2 \%$ which appears to be Top-Down. This means that signs displayed in schools come from the health department, both from the Malang City Government and the East Java Provincial 
Government. This issue arises because health is expensive in addition to reducing the government's budget for Insurance and Social Security (BPJS) spending. The issue of formalin, stale food, carbonated drinks which are consumed in excess is a common problem in urban communities, especially in the Great Malang area. Unhealthy snacks offered by food vendors have a negative impact on students. Students that experience the learning process at school certainly need adequate and balanced nutrition to learn well during long study hours such as from 07.00-16.00 WIB. Issues associated with discipline also correlate with students despite having a small frequency of occurrence at $2.8 \%$. This means that schools have students that lack discipline in attending classes, following lessons, uniformed rules, and borrowing books in the library. The poster was chosen to educate students to increase their level of discipline.

Issues of religion and nationalism also appear in the data, which indicates that religion such as Qur'anic verses is still relevant in reducing the negative effects of deviant social behavior. The text also targets on how to be sincere while serving the public.

In addition, national issues also arise such as welcoming Heroes' Day every November 10th, which is also relevant because it tends to encourage the spirit of patriotism, and nationality.

\subsection{The value of character education through $L L$}

Each school chooses the value of character education based on students and teachers' needs. The value of character education is also based on social problems that arise in the community where the location of students resides. The values of character education raised in the sign are expected to educate students to become agents of change in correcting social problems in the society.

Table 5. Values of character education

\begin{tabular}{cc}
\hline School & Values of Character Education \\
\hline A1-1 & Hard work, discipline, love peace \\
A2-1 & Hard work, creative, discipline \\
A2-2 & Nationalism spirit, discipline, religious, environment \\
care, love peace \\
K1-1 & Tolerance, environmental care, religious, hard work \\
K1-2 & Environment care, discipline \\
P1-1 & Discipline, hard work, tolerance, honest \\
P1-2 & Reading habits, environment care, love peace, \\
& religious, hard work, nationalism spirit \\
P1-3 & Discipline, hard work, reading habits, environment \\
P2-1 & care \\
P2-2 & Religious, discipline, honest, hard work \\
& Reading habits, environment care, love peace, \\
\end{tabular}

Table 5 shows that 9 components of character education values, namely hard work, creative, discipline, national spirit, religious, honesty, environmental care, reading hobbies, and love for peace were raised from the 18 components. This indicates that the 9 components are a "weapon" for schools and government to overcome the problems of students and the surrounding community.

\subsection{The Value of Character Education through Environmental Care}

Some signs display the topic of saving water as a source of life for living things.

Figures 8, 9, and 10 show the concepts of water-saving and utilization which contains persuasion, prohibition, and invitation. Education on greening targets the school environment, thereby making an important institution to instill a sense of concern for nature and the environment. Several attempts were made to promote greening, one of which was through posters that were displayed in schools.

Figures 11 and 12 show the background image with the atmosphere when greening occurs. Poster 4 with the sentence "Green is Beautiful, Green is Healthy" illustrates that greening creates a beautiful and healthy atmosphere which are promoted through greening. Poster 5 shows that the vision of the school needs to create a green school in a healthy atmosphere in the school environment, thereby making the students comfortable in learning to achieve success.

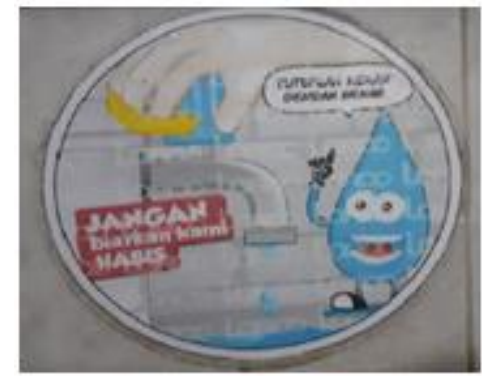

Figure 8. (A2-2/7)

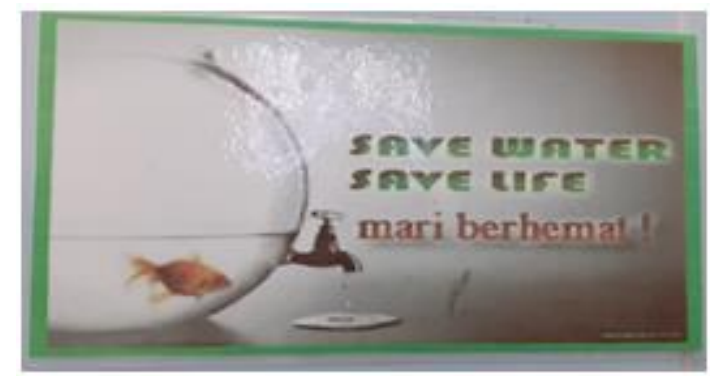

Figure 9. (A2-2/13)

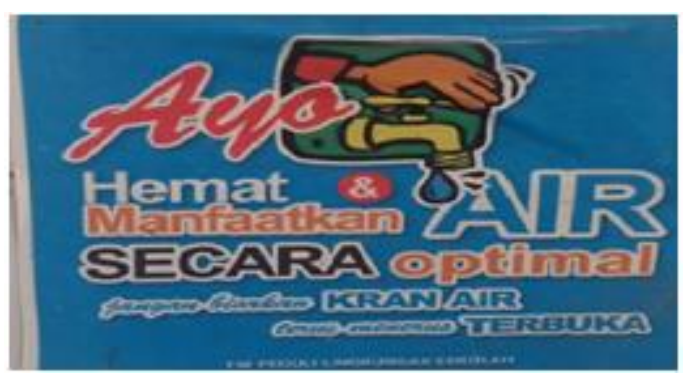

Figure 10. (K1-1/28)

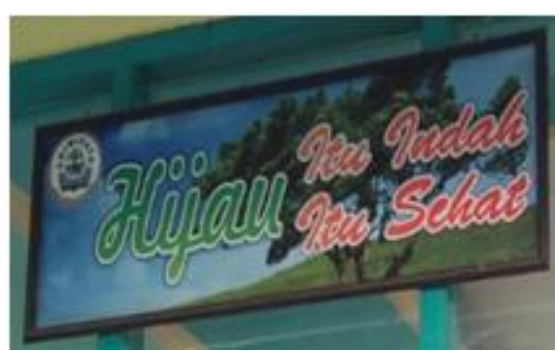

Figure 11. (K1-2/15) 


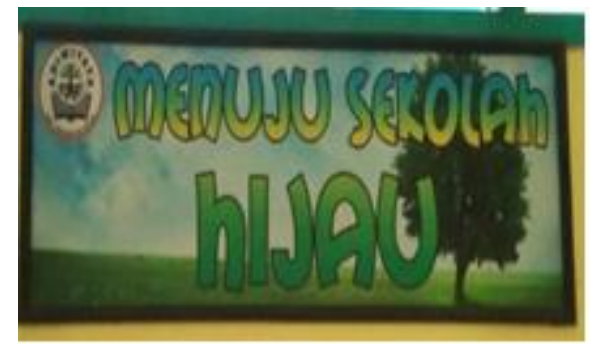

Figure 12. $(\mathrm{K} 1-2 / 16)$

Greening promotion is not only rhetorical, efforts were made, such as composting, extracting nails, planting trees, as shown in Figures 13, 14 and 15.

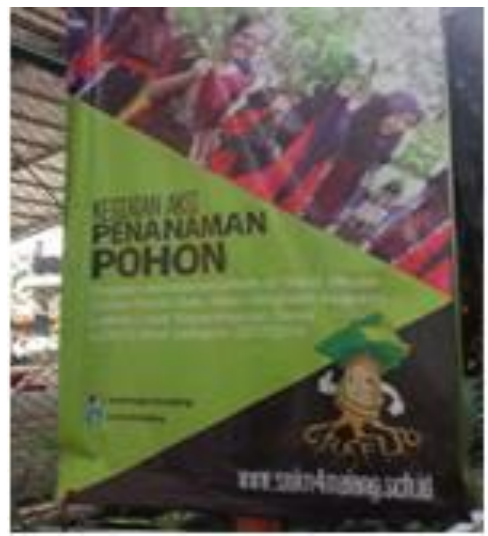

Figure 13. $(\mathrm{K} 1-1 / 37)$

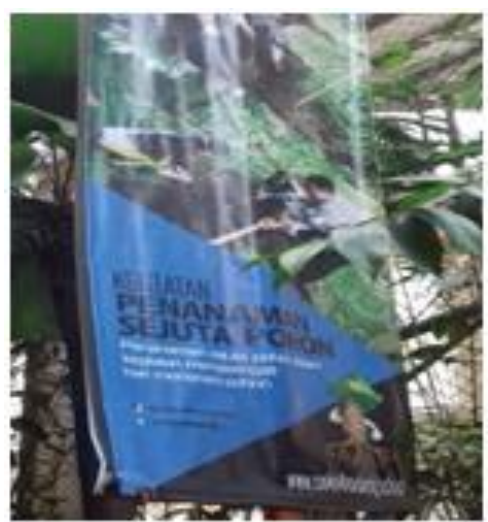

Figure 14. $(\mathrm{K} 1-1 / 38)$

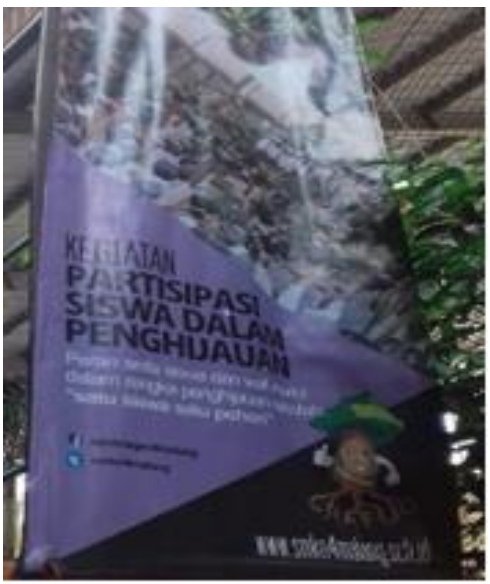

Figure 15. $(\mathrm{K} 1-1 / 40)$
Figures 13, 14, and 15 show a persuasion action, which encourage students to plant trees. It aims to instill awareness and sacrifice in nature conservation. Poster 8 shows a concrete action where one student is required to plant a tree.

The president and vice president elections left a serious problem associated with uncleanliness, due to the large number of banners and campaign billboards littered all over the place. After cleaning, it turns out the nails on installed banners and billboards were still stuck, especially in trees. The initiative emerged by holding the nail extraction movement on trees, as shown in Figure 16.

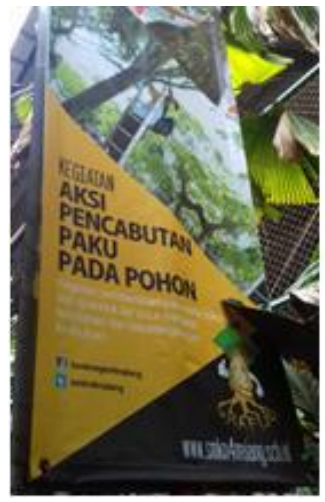

Figure 16. $(\mathrm{K} 1-1 / 32)$

Other environmental issues are waste and cleanliness which became a serious community problem that covers the culture of those that indiscriminately dispose garbage. Posters were also designed to educate students to throw trash in their place (Figures 17 and 18).

Figure 19 shows the prohibition on burning rubbish with the poster used to show illustrations of air pollution caused by burning garbage. It is hoped that the collected garbage is utilized and not burned.

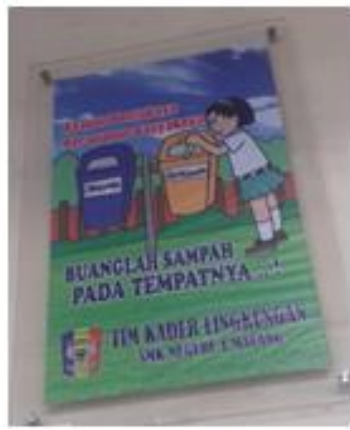

Figure 17. (K1-1/24)

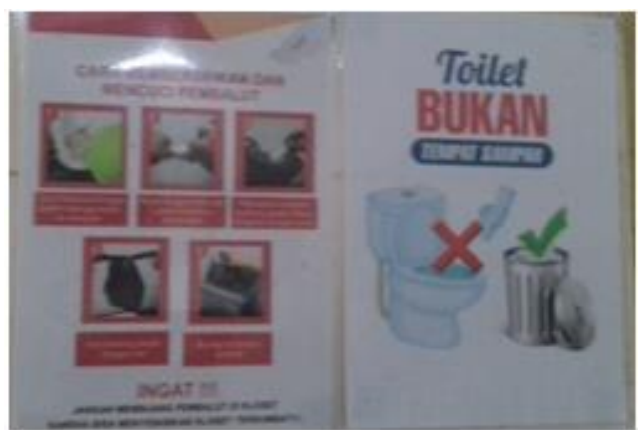

Figure 18. (K1-1/31) 


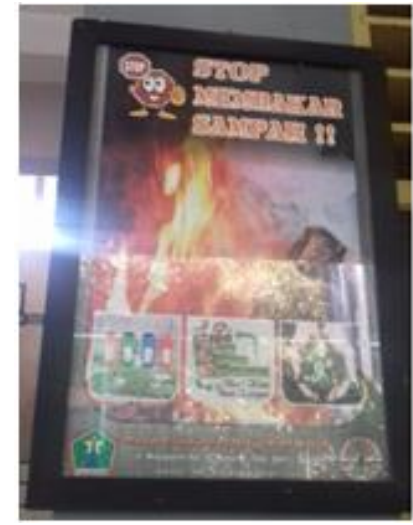

Figure 19. (K1-1/27)

\subsection{Character Education through Religious Values and Honesty in LL}

Religious values are very important to help overcome social problems with religion as a guideline to determine what is permitted and prohibited. Religion regulates how humans establish communication with God, humans, and nature. The rules in a well-run religion tend to facilitate human affairs in relation to fellow humans, nature, and God.

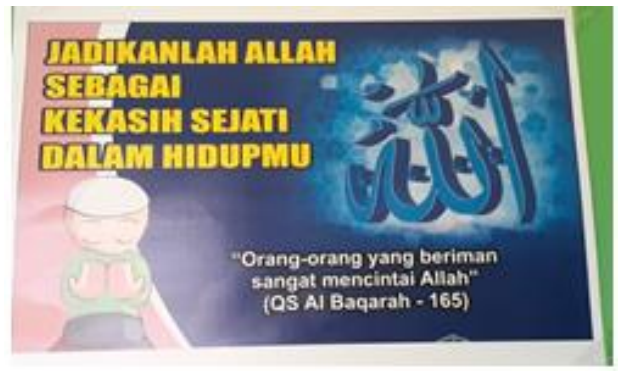

Figure 20. (P2-2/71)

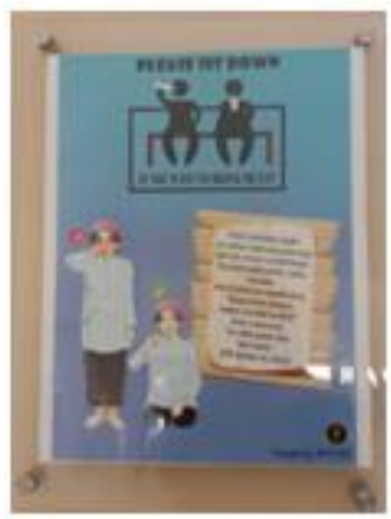

Figure 21. (A2-1/6)

Figure 20 uses Qur'anic Verses to form context correlation and message reinforcement with Arabic script bearing the word Allah used to show religious identity.

Figure 21 shows that humans need to desist from the habit of eating and drinking while standing in accordance with the order of the Prophet Muhammad. To reinforce the message, an excerpt from the proposition in the form of the hadith of the Prophet was written. Figure 22 shows the act of cultivating the soul and mental praiseworthy which is associated with honesty and devotion to God Almighty. Figure 23 states that faith is associated with God, and the nature of His creation, which maintains cleanliness. Figure 24 gives the message that work and service are worship, which is a matter of ritual and social behavior. Values are instilled in students' from the series of religious values, such as believing and being devoted to Allah SWT, the social environment, nature, and one's own personality.

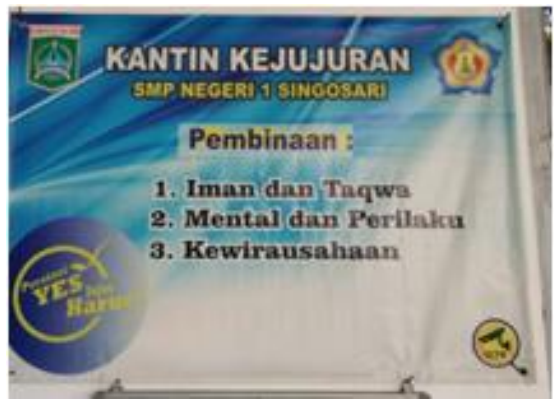

Figure 22. (P1-1/78)

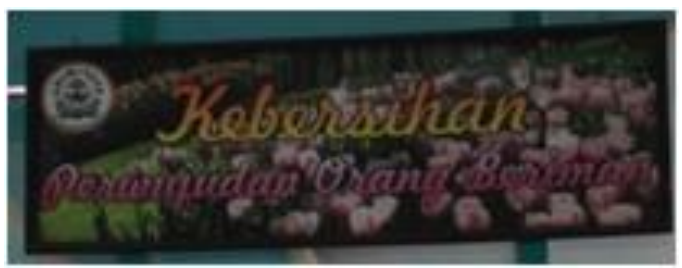

Figure 23. (K1-2/19)

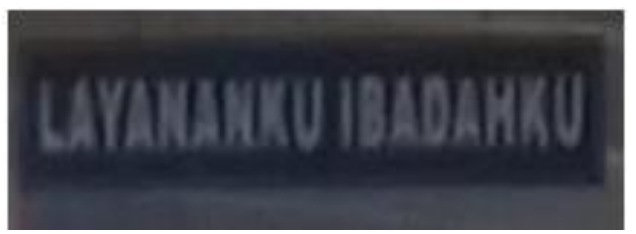

Figure 24. (K1-1/26)

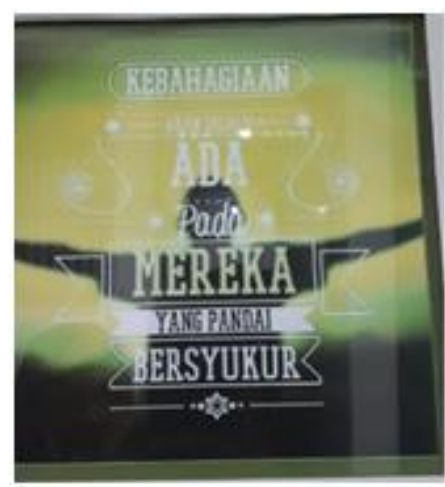

Figure 25. (A2-2/9)

Religious values conclude that faith and devotion to God gives a sense of happiness. Therefore, humans need to be grateful for the gift given to them by God. Gratitude is what drives us to happiness as shown in Figure 25.

\subsection{Character Education through the spirit of nationality and nationalism in $\mathbf{L L}$}

Students as the next generation of the nation need to a national spirit to understand that the Indonesian people have 
pluralism and nationalism are the adhesive power of this nation.

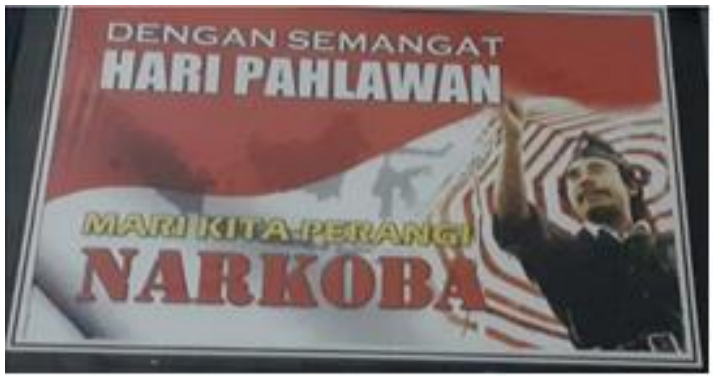

Figure 26. (A2-2/8)

Appreciating the spirit of the heroism by freedom fighters is a form of the spirit of nationalism. This spirit is also able to foster nationalism and national love with the spirit of selfsacrifice from heroes worth emulating. The Indonesian state stands on ethnicity, languages and religions. During the glory of the Majapahit Kingdom, the spirit of difference had already arisen with the motto Bhineka Tunggal Ika, Tan Hana Dharma Mangrwa (Diversity in Unity, There is no ambiguity in the truth). Irrespective of the differences that made the Indonesian people strong, the spirit of being taken for centuries is brought to the present era. Educating the spirit of nationalism can pass this way, which appreciates the diversity. Heroes' Day is a moment where diversity is not a unity breaker as shown in Figure 26. The spirit of sacrifice for the nation is fostered again and continues to be echoed to the younger generation to prevent the future of nationalism from being lost.

\subsection{Character education through hard work in LL}

The posters displayed at school area contain messages that encourage students to work hard (Figures 27 and 28). The concept is adjusted to the image, assignments, and responsibilities of students, such as studying tirelessly.

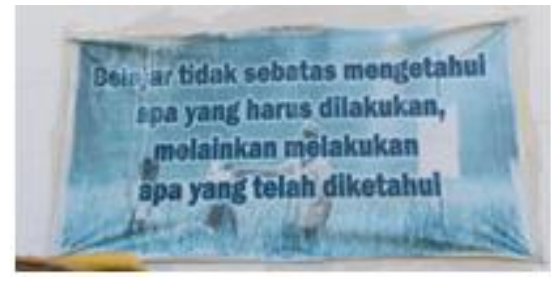

Figure 27. (P1-3/42)

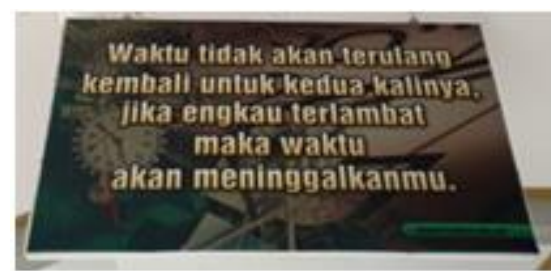

Figure 28. (P1-3/48)

\subsection{The value of character education through reading habits}

Figures 29-31 promote science as a very useful tool for the future. Reading books is a mandatory activity for every student as it enables them to acquire knowledge and information. Books are also a source of inspiration for them to enhance their creativity.

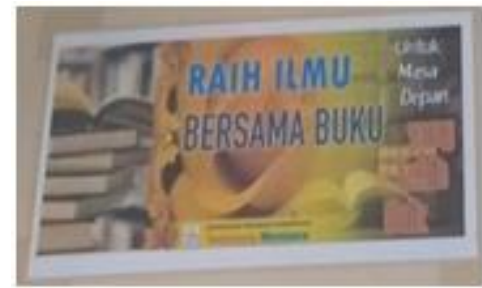

Figure 29. (P1-3/56)

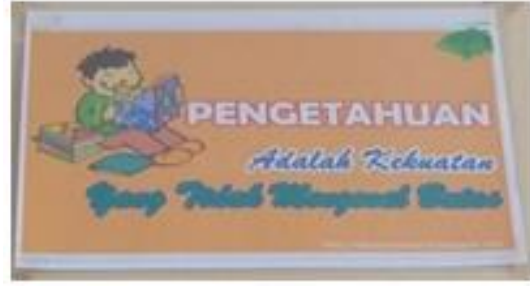

Figure 30. (P1-3/57)

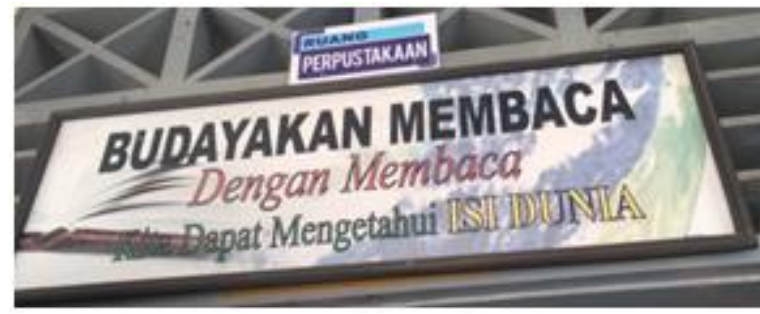

Figure 31. (P1-3/58)

Books are one way to obtain knowledge that are very useful for building the future, therefore, students need to cultivate the habit of reading. These signs target students that are unfamiliar with reading culture and the library provides books and only becomes a collection. Therefore, several things need to be carried out for students to possess the right reading habits, such as providing education and promoting reading habits through these signs.

\subsection{LL as a strategy for delivering messages on a large} scale

Indonesia is a developing country. Environmental problems, such as forest fires, felling trees, garbage, waste, and air pollution are common phenomena in developing countries. Environmental problems are related to social problems that arise in society. The issues of honesty, tolerance, discipline, working hard, and respecting others are social issues that form stereotypes in developing countries. These two issues are closely related, so solving them must also be done together.

School is a place to recognize values, science, knowledge, technology, religion, and culture. The entire space in the school can be used to instill these values. Various media can be maximized, especially public spaces. Through Linguistic Landscape, education about environmental preservation and the cultivation of values can be more conceptualized and organized. Landscape linguistics can also be a link between texts in the public space of one school and another. This connection can build messages on a bigger and stronger scale. 
This can invite greater attention from the government and society to contribute more to environmental and social issues.

\section{CONCLUSION}

Bahasa Indonesia dominates the LL sign in the school environment, which means that this language is easier to understand compared to others. The message in the sign needs high comprehension ability, therefore, Bahasa Indonesia is chosen to reduce misinterpretation. Its dominant appearance in the monolingual indicates that the chosen language stands alone to deliver messages. However, the emergence of Bahasa Indonesia in bilingual and multilingual proves its ability to combine with other languages to function as a translation or even an affirmation. This is also supported by language policies applied in education which shows that English is still considered a foreign language, Arabic represents Islamic religious symbols, and Javanese still accommodates locality and cultural symbols. The dominance of the emergence of Bahasa Indonesia turned Arabic and Javanese into marginal languages. Linguistic aspects of text construction are dominated by phrases and clauses. This indicates that the message from the sign is very effective using this linguistic aspect tool.

The use of English, Arabic, and Javanese in the LL is limited and tends to use familiar texts. Arabic is associated with the terms in surah as well as the verses of the Quran and hadith, while Javanese is obtained from proverbs that are common to the Javanese people. This is different from the use of Bahasa Indonesia which is more diverse and complex.

LL sign contains 18 character education messages out of which 9 were utilized. The total absence of components indicates that the problems faced by students and the community are not massive in their entirety. The application of character education acts as an alternative to solving social problems. Students are expected to be agents of change in society, thereby making them able to provide solutions to social problems that occur in their environment. However, indepth studies show that the dominance of environmental care indicates that students and the community are relatively less concerned about the environment. This is also seen in three themes that sequentially appear in LL, namely environment, attitudes and behavior, and motivation. This represents the problems facing society with hard work, creative, disciplined, national spirit, religious, honesty, reading habits, and love for peace as symptomatic social issues. Education through signs, evoke perceptions and attitudes which is used to strengthen character education in schools to solve social problems.

The results of this study inspire strategies that can be applied by schools in delivering social and environmental issues to students. Texts in public spaces can also develop in other themes, such as anti-corruption education, anti-bullying, anti-racism, and issues of radicalism. Between schools can forge a unified theme so that messages are spread more broadly and massively. These themes will develop broader and more complex research so that LL research related to school scape will develop and make a major contribution to society to solve problems. Previous research has focused more on language use and the information-symbolic function of language use in public spaces. This research will give color to previous research that lacks attention to environmental issues and the values of character education in schools.

The problems in Malang Raya are dominated by environmental and social issues. Certain cities have different issues, for example, issues of radicalism, disintegration, natural disasters, racism, and intolerance. From the characteristics of the issues faced by a city, schools in the city area are certainly affected by its education policy. This will have an impact on the policy of structuring the text for public spaces in the school. Linguistic Landscape will certainly make a contribution if it is moved in research in that direction. This is not only limited to research in Indonesia but in other countries.

\section{REFERENCES}

[1] Landry, R., Bourhis, R. (1997). Linguistic landscape and ethnolinguistic vitality: An empirical study. Journal of Language and Social Psychology, 16(1): 23-49. https://doi.org/10.1177/0261927X970161002

[2] Huebner, T. (2008). Bangkok's linguistic landscapes: Environmental print, codemixing and language change. International Journal of Multilingualism, 3(1): 31-51. https://doi.org/10.1080/14790710608668384

[3] Backhaus, P. (2008). Multilingualism in Tokyo: A look into the linguistic landscape. Int. J. Multiling., 3(1): 5266. https://doi.org/10.1080/14790710608668385

[4] Andriyanti, E. (2019). Linguistic landscape at Yogyakarta's senior high schools in multilingual context: Patterns and representation. Indones. J. Appl. Linguistics, 9(1): 85-97. https://doi.org/10.17509/ijal.v9i1.13841

[5] Kasanga, L.A. (2012). Mapping the linguistic landscape of a commercial neighbourhood in Central Phnom Penh. J. Multiling. Multicult. Dev., 33(6): 553-567. https://doi.org/10.1080/01434632.2012.683529

[6] Shohamy, E., Gorter, D. (2008). Linguistic Landscape Expanding the Scenery. Routledge, New York. https://doi.org/10.4324/9780203930960

[7] Ben-Rafael, E., Shohamy, E., Amara, M.H., TrumperHecht, N. (2006). Linguistic landscape as symbolic construction of the public space: The case of Israel. Int. $\begin{array}{lll}\text { J. } & \text { Multiling., } & \text { 3(1): }\end{array}$ https://doi.org/10.1080/14790710608668383

[8] Piller, I. (2001). Identity constructions in multilingual advertising. Lang. Soc., 30(2): 153-186. https://doi.org/10.1017/S0047404501002019

[9] Piller, I. (2003). 10. Advertising as a site of language contact. Annu. Rev. Appl. Linguist., 23: 170-183. https://doi.org/10.1017/s0267190503000254

[10] Cenoz, J., Gorter, D. (2006). Linguistic landscape and minority languages. International Journal of Multilingualism, $3(1)$ : 67-80. https://doi.org/10.1080/14790710608668386

[11] Gorter, D. (2013). Linguistic landscapes in a multilingual world. Annu. Rev. Appl. Linguist., 33: 190-212. https://doi.org/10.1017/S0267190513000020

[12] Hewitt-Bradshaw, I. (2014). Linguistic landscape as a language learning and literacy resource in Caribbean creole contexts. Caribb. Curric., 22(1): 157-173.

[13] Ivkovic, D., Lotherington, H. (2009). Multilingualism in cyberspace: Conceptualising the virtual linguistic landscape. Int. J. Multiling., 6(1): 17-36. https://doi.org/10.1080/14790710802582436

[14] Martínez, G.A. (2016). Vital signs: A photovoice assessment of the linguistic landscape in Spanish in healthcare facilities along the U.S.-Mexico border. Int. J. 
Commun. Heal., 2014(4): 17-24.

[15] Bruyèl-Olmedo, A., Juan-Garau, M. (2009). English as a lingua franca in the linguistic landscape of the multilingual resort of S'Arenal in Mallorca. Int. J. Multiling., 6(4): $386-411$ https://doi.org/10.1080/14790710903125010

[16] Reh, M. (2004). Multilingual writing: A reader-oriented typology-with examples from lira municipality (Uganda). Int. J. Soc. Lang., 2004(170): 1-41. https://doi.org/10.1515/ijsl.2004.2004.170.1

[17] Griffin, J.L. (2004). The presence of written English on the streets of Rome. English Today, 20(2): 3-8. https://doi.org/10.1017/S0266078404002020

[18] Manan, S.A., David, M.K., Dumanig, F.P., Naqeebullah, K. (2015). Politics, economics and identity: Mapping the linguistic landscape of Kuala Lumpur, Malaysia. Int. J. Multiling., 12(1):

$31-50$. https://doi.org/10.1080/14790718.2014.905581

[19] Coluzzi, P., Kitade, R. (2015). The languages of places of worship in the Kuala Lumpur area: A study on the 'religious' linguistic landscape in Malaysia. Linguist. Landscape, $1(3)$ :

243-267. https://doi.org/10.1075/11.1.3.03col

[20] Taylor-Leech, K.J. (2012). Language choice as an index of identity: Linguistic landscape in Dili, Timor-Leste. Int. J. $\quad$ Multiling., $9(1)$ : 15-34. https://doi.org/10.1080/14790718.2011.583654

[21] Shang, G., Guo, L. (2017). Linguistic landscape in Singapore: what shop names reveal about Singapore's multilingualism. Int. J. Multiling., 14(2): 183-201. https://doi.org/10.1080/14790718.2016.1218497

[22] Tang, H.K. (2018). Linguistic landscaping in Singapore: multilingualism or the dominance of English and its dual identity in the local linguistic ecology? Int. J. Multiling., 2: https://doi.org/10.1080/14790718.2018.1467422
[23] Prapobratanakul, C. (2016). Inside the shop names: Hybridity, language awareness and globalization in the linguistic landscape of a local commercial neighborhood in Bangkok. Manusya, 19(3): 26-37. https://doi.org/10.1163/26659077-01903003

[24] Yannuar, N., Tabiati, S.E. (2016). Public signs in the city of Malang: A study on the linguistic landscape of Indonesia. The Changing Face of Language Pedagogy: Exploring Linguistics and Literature, 1: 123-138. https://www.researchgate.net/publication/310425960

[25] da Silva, A.M. (2017). Exploring the language choice of the non-commercial signs in Jakarta. Indones. J. Appl. Linguist., $\quad 7(2)$ : 467-475. https://doi.org/10.17509/ijal.v7i2.8355

[26] Erikha, F. (2018). Konsep lanskap linguistik pada papan nama Jalan Kerajaan (Râjamârga): Studi kasus di kota Yogyakarta. Paradig. J. Kaji. Budaya, 8(1): 38. https://doi.org/10.17510/paradigma.v8i1.231

[27] Harbon, L., Halimi, S.S. (2019). A 'disjunct' in the linguistic landscape: Messages about food and nutrition in Indonesian school environments. Indones. J. Appl. Linguist., $\quad 8(3)$ : 567-576. https://doi.org/10.17509/ijal.v8i3.15263

[28] Oktaviani, E. (2019). Linguistic landscape: A case study of shop names in Gresik Kota Baru (GKB), Gresik. http://digilib.uinsby.ac.id/id/eprint/30926

[29] Fakhiroh, Z., Rohmah, Z. (2018). Linguistic Landscape in Sidoarjo City. NOBEL J. Lit. Lang. Teach., 9(2): 96116. https://doi.org/10.15642/nobel.2018.9.2.96-116

[30] Spradley, J. (2007). Metode Etnografi. 2nd Edition. Yogyakarta: Tiara Wacana.

[31] Wohlfart, I.K. (2017) Discourses in Place. In: Intergenerational Consequences of Lifestyle Migration. Springer, Singapore. https://doi.org/10.1007/978-98110-3260-8_3 